\title{
The Subject of Discourse Is the Public: Interpretation Based on One-Dimensional Man
}

\author{
Zhang Meng \\ Department of Philosophy, Faculty of Public Administration, Nanjing Normal University, Nanjing, China
}

Email address:

461371301@qq.com

\section{To cite this article:}

Zhang Meng. The Subject of Discourse Is the Public: Interpretation Based on One-Dimensional Man. Communication and Linguistics Studies. Vol. 7, No. 3, 2021, pp. 64-68. doi: 10.11648/j.cls.20210703.14

Received: October 4, 2021; Accepted: November 1, 2021; Published: November 5, 2021

\begin{abstract}
The paper is based on Herbert Marcuse's analysis of language in the One-Dimensional Man, it elaborates on the current problems in the field of discourse. With the continuous technological innovation, the improvement of productivity and efficiency separates discourse from the broadest public, and some people grab the ownership and use right of certain discourse. Moreover, the irregular use of language not only damages the language itself, but also destroys the discourse ecology, thus causing the defect of the public discourse right. Analyzing the impact of these phenomena on the society and the public is conducive to solving the injustice in the current society. The use of discourse should belong to all people, because everyone lives in the world equally. The author used literature analysis method to study the separation of discourse and the public in the current society from the interdisciplinary perspective, in order to call for renewed public attention to discourse. The concern of discourse ownership is the pursuit of fairness and justice. In the process of the public's equal enjoyment of all rights arising from language, it will not only promote the confirmation and play of human subjectivity, but also benefit the development of the whole society.
\end{abstract}

Keywords: Discourse, The Public, The Subject

\section{Introduction}

"At the nodal points of the universe of public discourse, self-validating, analytical propositions appear which function like magic-ritual formulas. Hammered and re-hammered into the recipient's mind, they produce the effect of enclosing it within the circle of the conditions prescribed by the formula." [1] In Marcuse depicted in the world, one public discourse due to cut public discussion and accepted way and become no longer has the public, it's coat draped in public, but is the lack of compressed for promotional and control certain significance of incomplete information, is closed in the field of discourse, is one of the characteristics of a social one. The field of discourse is shrinking, and operationalism has become the main feature of language. Discourse as a tool of rulers is gradually alienated, and the separation of the public from discourse hinders social freedom. Freedom "is actually within, obtained from finding our true identity" [2]. Reaffirming the meaning of discourse to the public is conducive to the widest participation of the public in social activities, to become the benefits and beneficiaries of social development.

\section{The Power of Discourse}

\subsection{The Resistance of Discourse}

In the developed industrial society, technology continues to innovate, and its rationality is constantly confirmed in the face of the huge material wealth it creates. "The power over man which this society has acquired is daily absolved by its efficacy and productiveness. [1] Social propaganda agencies become the intermediary between rulers and their dependents. The way discourse functions has changed, and the independent consciousness and free will required by discourse expression has become irrelevant. All steps in the process can remain or disappear according to whether they are needed or not. If the others do not agree, they will "resort to rhetoric, propaganda, marshalling of additional facts, psychological tricks, threats, bribes, torture, mockery, promises, of protection, and a variety of other expedients." [3] This is the function of discourse in the hands of the rulers, as the means by which the governed and their intermediaries are properly propagated according to the needs of the moment in order to 
achieve their ends. Discourse is used for operation. In order to play the role needed by people on the necessary occasions, it can appear in many faces, but it can always keep the same standard. The former requires people to attach "color" to it constantly, so as to realize the statement in different meaning context; The latter, like machine languages, exist in standardized formats, "The word becomes cliché and, as cliché, governs the speech or the writing; the communication thus precludes genuine development of meaning". [1] In this state, discourse is the product of desire and artificial propaganda materials created according to the needs of self-interest groups. It betrays its own nature and is alienated into a force against itself to some extent. "However, the authoritarian ritualization of discourse is more striking where it affects the dialectical language itself." [1] It relies on unthinking dissemination under the guise of authority, supplemented to a limited extent by violence, called propaganda but really indoctrination, coexisting with terror. "More specific in totalitarian propaganda, however, than direct threats and crimes against individuals is the use of indirect, veiled, and menacing hints against all who will not heed its teachings and, later, mass murder perpetrated on "guilty" and "innocent" alike." [4] Totalitarian discourse monopolizes all fields of communication and discussion, and relies on power to terminate the free discourse of science, which is autocratic and seditious. "The power of words is so great that it suffices to designate in well-chosen terms the most odious things to make them acceptable to crowds." [5] In all these communications, the public is neither the creator nor the disseminator of the discourse, but only the receiver and listener.

The development of the Internet has endowed discourse with new roles, and letters such as GKD (means do it quickly) has become popular. These acronyms are often circulated among peers or peers. Among these groups, acronyms of words and phrases are considered as means to simplify communication, but they often fail to survive once they are "out of the circle". In the whole discourse ecology, abbreviations actually dissolve concepts, which is what Marcuse calls "unidirectional language". The unidirectional language enlarges the unified ellipsis language and loses its own cognitive value, as well as the ideographic function of Chinese characters. "If the linguistic behaviour blocks conceptual development, if it militates against abstraction and mediation, if it surrenders to the immediate facts, it repels recognition of the factors behind the facts, and thus replels recognition of the facts, and of their historical content." [1] The use of abbreviated utterances has severed the relationship between people and factual content, and formalized language has replaced the substantive essence of concepts. Such rigid images and simple formulas have increasingly alienated the public from the real history.

\subsection{The Public Need Discourse}

Concepts have certain referential properties, but they are by no means just descriptions of special things. The concept of discourse dependence is expressed in a certain logical form and transmits information in a certain field based on factual experience. The subject of information is the public, and the public needs discourse. To some extent, discourse is a necessary means for public survival and development. The public creates and even operates discourse at certain times. When it accurately expresses information, its authenticity is beyond doubt, but when it expresses individual or group positions, its authenticity is immediately impaired and takes on a particular personal meaning with the characteristics of subjective expression.

The development of the Internet will be anywhere in the world of real-time information to the public, but because of cultural differences in language and regional restrictions, the difference of thinking ability and time of energy, most of the public do not fully understand the present world, only in one of the few information analysis of the world, in the process, discourse is the public's understanding of the world platform. If the platform does not completely belong to the public, the world that is not clear to the public will be covered with a veil, and even its true appearance will be completely changed, so that the public can never directly participate in the world affairs. "Who is, in the classical conception, the subject that comprehends the ontological condition of truth and untruth? It is the master of pure contemplation (theoria), and the master of practice guided by theoria, i.e., the philosopher-statesman. To be sure, the truth which he knows and expounds is potentially accessible to everyone." [1] Although the common people could approach the truth under the guidance of the master, in the Ancient Greek tradition, the philosopher-statesman was the first subject in possession of truth and truth, because at that time the thinking activity was monopolized by this group, the contemplative life and the action life were divided, the thinking activity was opposed to the practice activity. The object of contemplative life has little to do with the concrete practical affairs of mankind, while the life of action, which is really concerned with human life, lacks thought. Obviously, this situation is not reasonable, thinking should not be the privilege of a few people, and everyone should be free and independent ability, the public is the main body of the truth and the truth, words given the public's understanding of the world basic data on the basis of practice and output for the public to the world to achieve this, discourse is necessary in the hands of the public.

The idea that one must constantly study the world in order to rule it plays only a small part in political thinking. It has little effect because there has been little progress in reporting the world in a way conducive to governance from the time of Aristotle to the time when the premise of democracy was established. The publicity of discourse endows the power of discourse governance, and the upper person can operate discourse according to his own planning of the current situation to control the public. In this sense, the public is subject to discourse and communicates with the superior through discourse, while the superior "wins" the public in this way. "They will somehow seek to control the behavior of others, if not by positive law then at least by persuasion. When men are in that posture toward events they are a public, as I am 
here defining the term; their opinions as to how others ought to behave are public opinions." [6] But the consequence of this is that the public is increasingly far away from the truth, even unable to face reality intuitively and think about it independently. "Freedom of speech is a matter of having some control over our own voices, which means having a say in who we are and how we are seen, and not having these things fixed for us by those in positions of superior power.'[7] If we admit that everyone is born equal and can equally know and enjoy the truth, then discourse is not necessarily a tool for controlling the public, but an energy with extensive practical value that is born in the public's equal and free communication, and achieves the effect of ridding the world of enchantment. Public discourse and public discourse can only really happen if we believe that.

\section{The Public Access to Discourse}

\subsection{Understand the Means of Communication}

"Technical progress, extended to the whole system of domination and coordination, creats forms of life (and of power) which appear to reconcile the forces opposing the system and to defeat or refute all protest in the name of the historical prospects of freedom from toil and domination." [1] The achievements of science and technology to create gradually become the basis of the rule management, master of science and technology people can more effective use of natural and social resources, and the means for the most part manipulated the words, when people get used to this compared with the traditional discourse platform for new forms of technology, once the new methods are limited, people will do. This is one of the ways in which new technology betrays the public. It can either give the public maximum convenience or it can always be used to block the public's path to freedom. Under the rule of science and technology, the society as a whole all the opposition and opposition, technical rule to the power of an ideological infiltration in the fields of politics, culture, language and thought, people losing their negative, critical, become one-dimensional people, living in the society have become one-dimensional society. Technology has no attributes, but the people who use it have specific positions. Technological neutrality is no longer possible in advanced industrial societies. Therefore, if the public is not to be troubled by this kind of wavering technology, on the one hand, it needs to pay attention to the abyss beneath the surface of efficiency and convenience, on the other hand, it needs to actively grasp this advantage. For the former, the public has to set rules to control the evil desires, while for the latter, discourse is most likely to belong to the public only when the public has the widest range of technical means. People without weapons are unable to discuss peace with those with weapons, so is the struggle for discourse power.

\subsection{Participate in the Formulation of Rules}

"Because actions are produced as the result of the interaction of the agent's beliefs and desires and the explanation of behavior is causal, reasons for action must entail desires." [8] People want to solve problems when they are affected. When problems arise, people may wonder whether existing rules are flawed. In order to get the answer to this question, people must study whether the rules are feasible to the largest extent. Therefore, those who participate in the study of rules must not be egoistic, they should consider the public will in the most extensive range of reasonable social requirements, and represent the universality of the public when making rules, that is to say, the subject of making rules must be the public. "Just as the multitude produces in common, just as it produces the common, it can produce political decisions." [9] In this way, the most recognizable rules can protect the interests and voice of the public. The public should take their place in the society, acknowledge the complexity of the society and the limitation of people, reflect on rules and strategies, and consider whether the relationship between individual people and the society needs to integrate different complex relationships into an organic whole, and the public should participate in it.

\subsection{Be Alert to the Control of Others}

"The vicissitudes of the language have their parallel in the vicissitudes of political behaviour. In the sale of equipment for relaxing entertainment in bomb shelters, in the television show of competing candidates for national leadership, the juncture between politics, business, and fun is complete." [1] In highly developed industrial societies, where politics operates on the basis of certain entertainment and commercial models, political language is no different from advertising language, and the control of language penetrates into all fields, thereby increasing the power of professional politicians to the point of gradually breaking away from the institutions they once benefited from and even strengthening control in the name of it. "Some practices clearly and systematically deprive individuals of what's necessary for a minimally decent life, or the development of basic capabilities." [10] On the contrary, the power of the public is gradually lost. They receive incomplete information, which limits the basis for their thinking, and then narrow the scope of their participation through incomplete thinking results. The public can only lose continuously. "Moreover, the etymological origin of power suggests the importance of power as a quality (an ability) which, however important, diverts appreciation of power as a relation and one that induces effects, especially in the making of human subjects and social orders." [11] The struggle for discourse power is not always achieved overnight. In the paralytic entertainment and commercial activities, the public gradually loses the dominant position of discourse in their own casual way. Absolutely, "nothingness constitutes the separation" [12]. If the public wants to master the initiative in this process, it must be alert to language, which may cause control. Language spreads information rather than orders, and everyone has the right to choose freely. If there is a language that the public has to obey, the meaning of language will be lost. 


\subsection{Choose the Right Representative}

While the power of discourse needs to be in the hands of the public, we know that not all members of the public are capable of sound judgment. The rational exchange of opposing values makes the views held by the opposing sides merge and penetrate each other in the process of struggle, while the irrational exchange of opposing values leads to the gradual unidirectional thinking mode of people, showing the characteristics of simple binary opposition. Different from Marcuse's unidirectional thinking mode, in which people have only positive consciousness, people have only irrational negative consciousness under simple dualistic thinking. Professional work needs people with professional knowledge to ensure efficiency and avoid Socratic tragedies. "The views of a world-famous musician on subjects such as the economy or global warming carry no special weight if the only authority behind them is the musician's musical accomplishments." [13] Therefore, we need to delimit the power of discourse in different fields so that the public is the fairest subject of the power of discourse. This means that the public cannot necessarily directly participate in public affairs, they need to choose appropriate agents to express their will, which is the process of political activities and the step of democratic practice, so that the public can consolidate their subject status and realize self-liberation. Agents are expected to abstract the collective opinions of the public from a complex set of events, and in some cases to ignore the opinions of individuals and specific groups. "Each individual is motivated to act by self-interest, and a rational choice is necessary for an action to achieve greatest advantage." [14] While choosing surrogates to represent oneself is both fair and efficient, surrogates are not always trustworthy. "Meeting in assembly, the individuals are the individuals are the spokesmen (often unaware) of institutions, interests embodied in organizations. In their decision (vote, pressure, propaganda) - itself the outcome of competing institutions and interests-the Nation, the Party, the Corporation, the University is set in motion, preserved, and reproduced-as a (relativaly) ultimate, universal reality, overriding the particular institutions or peoples subjected to it." [1] Ordinary people chose to let others to represent their once then means that you will be at the periphery of the event to the identity of the onlookers watched his things, so this is a prudent activity, in the choice of each link do to care for will only be possible to avoid the agent's desire to achieve the clearest advantage in the first place.

\section{Conclusion}

The application of public discourse is reflected in every aspect of life, and it is an important embodiment of people's participation in social affairs. In the public domain, people show through their actions that they belong to the nature of the world. The use of modern technology to participate widely in public life is an important way for people to build connections, the connection between people bears witness to the reality of man and thus establishes man's place in the world. Therefore, the mastery of discourse is related to the manifestation of the public's personal value.

In areas where technology is gradually dominant, discourse and technology are in collusion, and the public's right to freely decide their own lives is constantly restricted. Such restrictions exist in the field of people's activities in the name of efficiency, which is a nightmare that the public cannot get rid of. The seemingly indoctrination of the news media fills public life with wonders, but with it comes a great emptiness of the imagination of the future. The public discourse no longer needs thinking and interpretation, which is the destruction of the art of life by the developed one-way society. Discourse being mastered by the public is not only conducive to the display of personal value, but more importantly, it is conducive to breaking the limitations of a single world and providing a free world for the public. "The idea of an all-encompassing language is not foremost here; rather, the idea of a language that is at all times criticizable and inclusive, one that can still be generalized and becomes, for that very reason, more concrete." [15] In the broadest participation in social affairs, people will find the diversity and inclusiveness of the world, and thus act with a more equal attitude, which is conducive to the construction of the world.

\section{References}

[1] Herbert Marcuse (1964). One-Dimensional Man. London: Routledge \& Kegan Paul.

[2] Martin Cohen (2001). Political Philosophy From Plato to Mao. London: Pluto Press.

[3] R. M. Hare (1952). The Language of Morals. Oxford: Clarendon Press.

[4] Hannah Arendt (1973). The Origins of Totalitarianism. New York: Harcourt Brace \& Company.

[5] Gustave Le Bon (1896). The Crowd. New York: Dover Publications, Inc.

[6] Walter Lippmann (1993). The Phantom Public. New Jersey: Transaction Publishers.

[7] Lorna Finlayson (2015). The Political is Political. New York: Rowman \& Littlefield International, Ltd.

[8] David O. Brink (1989). Moral Realism and the Foundations of Ethics. Cambridge: Cambridge University Press.

[9] Michael Hardt and Antonio Negri (2004). Multitude War and Democracy in the Age of Empire. New York: The Penguin Press.

[10] David Sobel, Peter Vallentyne, and Steven Wall (2021). Oxford Studies in Political Philosophy. London: Oxford University Press.

[11] John S. Dryzek, Bonnie Honig, and Anne Phillips (2006). The Oxford Handbook of Political Theory. London: Oxford University Press. 
[12] Sebastian Gardner (2009). Sartre's Being and Nothingness: A Reader's Guide. London: Continuum.

[13] D. Q. Mclnerny (2004). Being Logical. New York: Random House.

[14] Nicholas Bunnin and Jiyuan Yu (2004). The Blackwell
Dictionary of Western Philosophy. Oxford: Blackwell Publishing.

[15] Rainer Forst (1994). Contexts of Justice: Political Philosophy beyond Liberalism and Communitarianism. Berkeley: University of California Press. 